環境感染誌 Vol. 36 no. 4, 2021

〈proceedings〉

\title{
外部委託職員と共働して行う環境衛生
}

目崎恵

\section{Environmental Hygiene in Collaboration with Outsourced Staff}

\author{
Megumi MEZAKI
}

Medical Safety Management, Uonuma Kikan Hospital, Niigata Prefectural Community Medicine Institute

$(2020$ 年 11 月 3 日受付 $\cdot 2021$ 年 3 月 10 日受理)

要 旨

環境衛生は医療関連感染を制御するための方策の一つである. 現在, 多くの施設で清掃等環境衛 生に係る業務を事業者に委託しており, 病院職員のみならず委託職員も医療関連感染制御において 非常に重要な役割を担っている.

環境衛生を委託職員に任せきりにするのではなく, 感染管理担当者が積極的に関与していかなけ れば環境衛生の質の向上は期待できない.

当施設においては, 環境衛生に取組むための体制を構築し, 病院職員と委託職員とが共働してチー ム活動を行っている.

その結果, 委託職員の目的意識抢よび当施設の環境衛生の質は向上した. 現在までに, 薬剤耐性 菌, インフルエンザ, Clostridioides difficile 感染症によるアウトブレイクの発生はない. 体制の構 築とチーム活動が奏功したと示唆される。

Key words : 環境衛生, 外部委託, チーム

\section{はじめに}

医療関連感染の制御において, 環境衛生は今や欠かせ ない位置づけとなっている。一般細菌は環境表面に数か 月生存すること ${ }^{1)}$, 多剤耐性菌に感染または保菌してい た患者の病室に新規入院患者が入院する場合, 多剂耐性 菌を獲得するリスクが増加すること采が示されており， 病院や施設内環境は見た目が清潔であるのは勿論のこと, 環境に由来する感染リスクとなる微生物を可能な限り減 少させ, 安全安心な療養環境を提供することが同時に重 要となる。

医療関連サービス振興会実態調査による病院清掃委託 率は $87.5 \%$ と高く ${ }^{3)}$, 現在多くの病院で委託職員が清掃 業務を担っている. 高頻度接触面やトイレ, 污物室, シ ンク等の水回り環境は, 微生物污染リスクの高い場所で あり, 環境衛生に際しては非常に重要な箇所となるが, その清掃を委託職員が担っていることも多い. 環境衛生 を委託職員に任せきりにするのではなく, 病院職員と委

新潟県地域医療推進機構魚沼基幹病院医療安全管理室
託職員とが共働し環境衛生に取り組むことが重要となる。

\section{1. 活動前の課題}

環境衛生の質を高めるためには, 病院職員のみならず 委託職員も医療関連感染を制御するという目的，また役 割を認識し業務を担うことが重要な鍵となる。しかし， 実際の委託職員の作業状況を確認すると, 清掃手順や方 法が統一されていない, 手袋を着用したまま業務を続け ている, 床を清拭した後に手指衛生を実施しない等, 感 染管理を担当する立場から，問題と感じる場面を目の当 たりにすることが当施設においてはしばしば見られてい た。「手袋はここで交換してください」「污い場所を触っ た後にきれいな場所を触らないでください」とその場で 直接指導しても一時的に改善はするが継続しない. なぜ そうしなければならないのか, 目的の理解なしには, 根 本的な解決には結びつかないだろう.

医療法施行規則第 9 条 $15^{4)}$ においては, 病院が清掃を 外部に業務委託する際「標準作業書」を常備し従事者に 周知していること，また業務内容及び作業方法を記した 


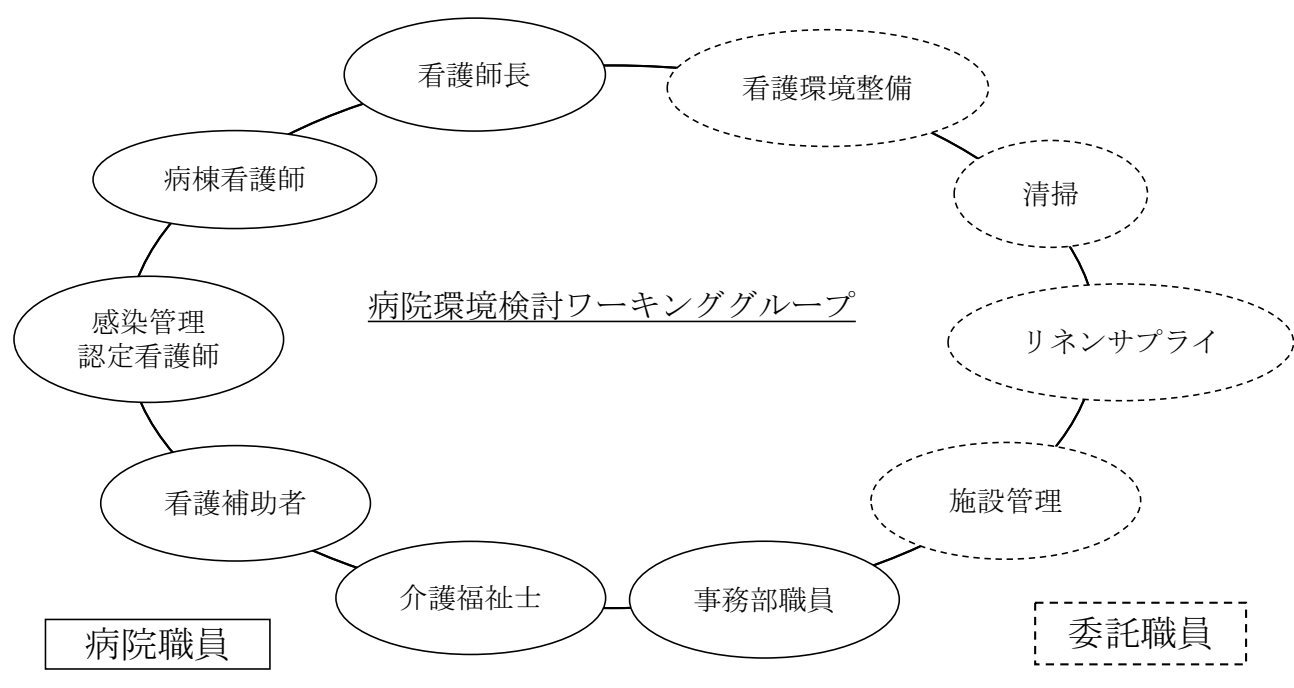

図 1 当施設におけるチーム（病院環境検討ワーキンググループ）の構成

「業務案内書」を作成し作業を行うことが規定されてい る. 感染管理担当者として「標準作業書」や「業務案内 書」に関与する事, またその遵守状況を確認することは 重要な責務であり，委託職員に環境衛生を任せきりにす るのではなく, 病院職員と委託職員とが, 目的や現場で 起きている問題を共有し, 改善に向け共に取り組むこと が重要となる。しかしその一方で組織体制や教育体制が 構築されていない現状があった。

\section{2. 課題に対する対策}

1）活動の基盤としての環境衛生に係る体制の構築

\section{(1) 組織体制の構築}

病院職員と委託職員とが環境衛生における問題につい て共有し, 安全安心な療養環境を提供する事を目的に, 当施設において病院環境検討ワーキンググループという チーム（以下チーム）を立ち上げた。

このチームは病院職員（看護師長, 感染管理認定看護 師, 病棟看護師, 介護福祉士, 看護補助者, 事務部職員) と環境衛生に関わる委託職員 (清掃, 看護環境整備, リ ネンサプライ, 施設管理) で構成している. 病院, 施設 内では多岐にわたり業務委託がされているが, 清潔な寝 具類を提供するリネンサプライ受託業者, 清潔な水の供 給や空気清浄度管理を行う施設管理受託業者も環境衛生 において重要な役割を果たしていることから構成員とし ている(図1).

また，チームを感染管理組織体制内に位置付け，委託 職員も病院職員の一員であることを認識し活動できるよ うにしている。組織化することで, 病院職員と委託職員 との連携が行いやすく, 検討する時間や機会を確保する ことが可能となる. また感染管理委員会, 感染対策部会 等院内委員会と同様, チームの規約を作成している.
（2）教育体制の確立

委託職員リーダーの知識, 技術の向上と, 役割認識を 深めることを目的に，研修の企画と実施の主体を，感染 管理担当者から委託職員リーダーへ，体制を移行した.

月に 1 回開催される研修会に感染管理担当者は同席し 内容の確認と共有を行っている. 委託職員リーダー自ら が主体となり研修を実施する事で, 委託職員リーダー自 身の学習の機会となり, また現場に即した具体的内容を 組み入れていることから実践へとつなげられている。

\section{2）体制構築後のチーム活動の実際}

チームの主な活動内容はミーティングと院内ラウンド である。

ミーティングは月に 1 回開催している. 業務を行う中 で, 環境衛生について問題と感じること, 気づいたこと について問題提起し, どうしたら改善できるかを, 構成 員がそれぞれの立場で考え検討を行っている．多くの意 見が集まる場所であり論点がずれることもあるが，目的 と役割について示し，ミーティングを進行している. 具 体的に提起された問題としては，「環境清拭手順が人そ れぞれで正しい方法がわからない」「高頻度接触面の清 拭と床の清掃が完了していないが, 寝具交換が終了して いることで退院時清掃が終了したと判断し，新規入院患 者を受け入れている現状がある」「病室カーテンが污染 されたままになっている」「ベッド柵の穴にほこりがた まっている」等様々である. 問題提起された事項に関し ては, 些細なことでも一つずつ確実に検討し, 改善へと つなげている.

院内ラウンドは月に 2 回実施し, 病棟を中心に院内全 体のラウンドを行っている. 具体的な内容として, ミー ティングで問題提起された箇所についての実際の現場の 確認, 退院時清掃の評価（インスペクション）の実施, 
埃がたまっている場所はないか, 共用トイレや污物室は 清潔に管理されているか，環境清拭手順を遵守できてい るか等, 確認を行っている. 実際のラウンドでは, 誰も 清掃していない箇所が確認されることもあり，その際は， 確実に定期清掃が行えるよう事務部職員と調整を図って いる.

\section{3. チーム活動により改善が図れた事例}

\section{1）環境清拭手順と方法の統一}

高頻度接触面を含む患者周囲の環境清拭は, 1 日 1 回 実施することと規定しているが，どのように実施するの かは個人の力量に任せられており, その順序, 清拭の仕 方は各人各様の方法となっていた. 手順が統一されてい ないことから, 不潔区域から清潔区域を清拭しているこ とや, 消毒剤含侵ワイプの交換のタイミングがわからず, 裏返して使用を続けている状況も見られ, 目に見える活 染は除去することができても, 微生物を減少させる本来 の目的を達成する環境清拭の実施が行えていなかった。 その原因に環境清拭手順書が存在していないことが考え られた。

そこで委託職員と一緒に「環境清拭手順書」の作成を 行った．委託職員のみ，あるいは病院職員のみで作成す るのではなく, 委託職員と病院職員とが共に検討しなが ら作成することで, 作業上の問題点やリスクとなりうる 場面について共有する事が出来た。 具体例として「ベッ ドの頭側と足側はどちらから清拭する必要があるのか」 「どのように清拭すれば微生物が除去されるのか」「環境 清拭クロスは何枚必要となるか」等を検討しながら作成 した，環境清拭手順書には，消毒剤含侵ワイプや手袋を 交換する夕イミング, 手指衛生を行う夕イミング, オー バーテーブル等の水平面の清拭の仕方（一方向に S の 字を描く清拭）等, 手順に沿って一項目ずつ写真とポイ ントを揭載した。

環境清拭手順書作成後は，環境清拭を実施するすべて の職員を対象に，なぜその手順と方法が必要なのかを理 解し，実践に結び付けられるよう教育の機会を設けた。 また，環境清拭手順書はいつでも確認できるよう，環境 清拭時に使用するワゴンに乗せ活用をしている.

環境清拭手順書の作成により統一した環境清拭が行え るようになった。 また, 病院職員, 委託職員双方が環境 清拭手順書を共有していることで, 作業時の手順の確認 や指導が行いやすい状況となっている.

\section{2）退院時清掃の確実な実施}

退院時清掃において, 清潔な寝具が取り付けられた後 にベッドを含む高頻度接触面の清拭が行われ（その逆も ある)，清潔になった場所が次の作業で污染されかねな い状況が見られた。これは, 退院時清掃には複数の委託 職員（清掃, 看護環境整備, リネンサプライ）が関与し,
それぞれの委託職員が, 時間が確保できたタイミングで しか作業を行えない状況に問題があると考えられた．外 部委託業者同士が時間を調整しあいながら数多くの退院 時清掃を実施するのは困難であり，契約内容自体の見直 しが必要と考えられた。

そこで，チームの構成員でもある事務部職員と委託契 約内容の見直しを行った. 契約更新の時期に合わせる必 要があり時間を要したが, 複数の外部委託業者が携わる のではなく 1 社で退院時清掃が完結できるよう契約内容 を変更した。

また寝具交換が終了していれば病室清掃が終了してい ると病棟職員は判断し, 退院時清掃がすべて完了してい ない状態で新規入院患者を受け入れている問題も明確化 した．これは, 退院時清掃が確実に終了しているのか確 認するすべがない事が原因であると考えられた。

そこで「退院病床清掃確認シート」（図 2）を作成し 活用することとした。病棟職員は，患者が退院した時点 で, 退室病床に「退院病床清掃確認シート」を置き, 各 担当者は手順に沿って確実に実施すべき項目を実施し, 責任をもってチェックとサインを行う。 そして病棟職員 は，全ての項目にチェックが入ったことを確認し，新規 入院患者を受け入れるよう仕組み化した。このことで, 退院時清掃を正しい順序で確実に実施したのち，新規入 院患者を受け入れることが可能となった.

現在, 委託清掃職員とともにランダムに退院時清掃評 価を実施（目視法, ATP 測定法, 蛍光塗料法）してい るが問題は見られていない.

\section{3）污染された病室カーテン交換}

病室カーテンは当施設においては，定期的に交換する， 污染時に交換する, 接触感染予防策実施後に交換するこ とと規定している。しかし実際は，接触感染予防策実施 後のカーテン交換は行われているが, 污染したカーテン についてはそのまま継続使用している問題が明らかに なった。退院時に病棟職員が污染状況について確認し, 污染時は交換依頼することを決め事としていたが，個人 の感覚により污染の程度の判断が様々であること, また 退院時にカーテンの污染状況を確認することは業務上困 難であるとの意見が聞かれた.

そこで, 退院病床清掃確認シート内に, カーテン污染 状況の確認項目を追加し, 退院時清掃を実施している清 掃職員がカーテンを確認し，污染時にはリネンサプライ 職員へ連絡する体制へと変更した。 カーテン污染状況を 確認する職員を変更し標準化することで, 污染時のカー テン交換実施が可能となった。

\section{4. 活動の評価}

チーム活動を開始し 3 年が経過した時点で，外部清掃 委託職員へアンケート調査を実施した。「清掃や環境整 


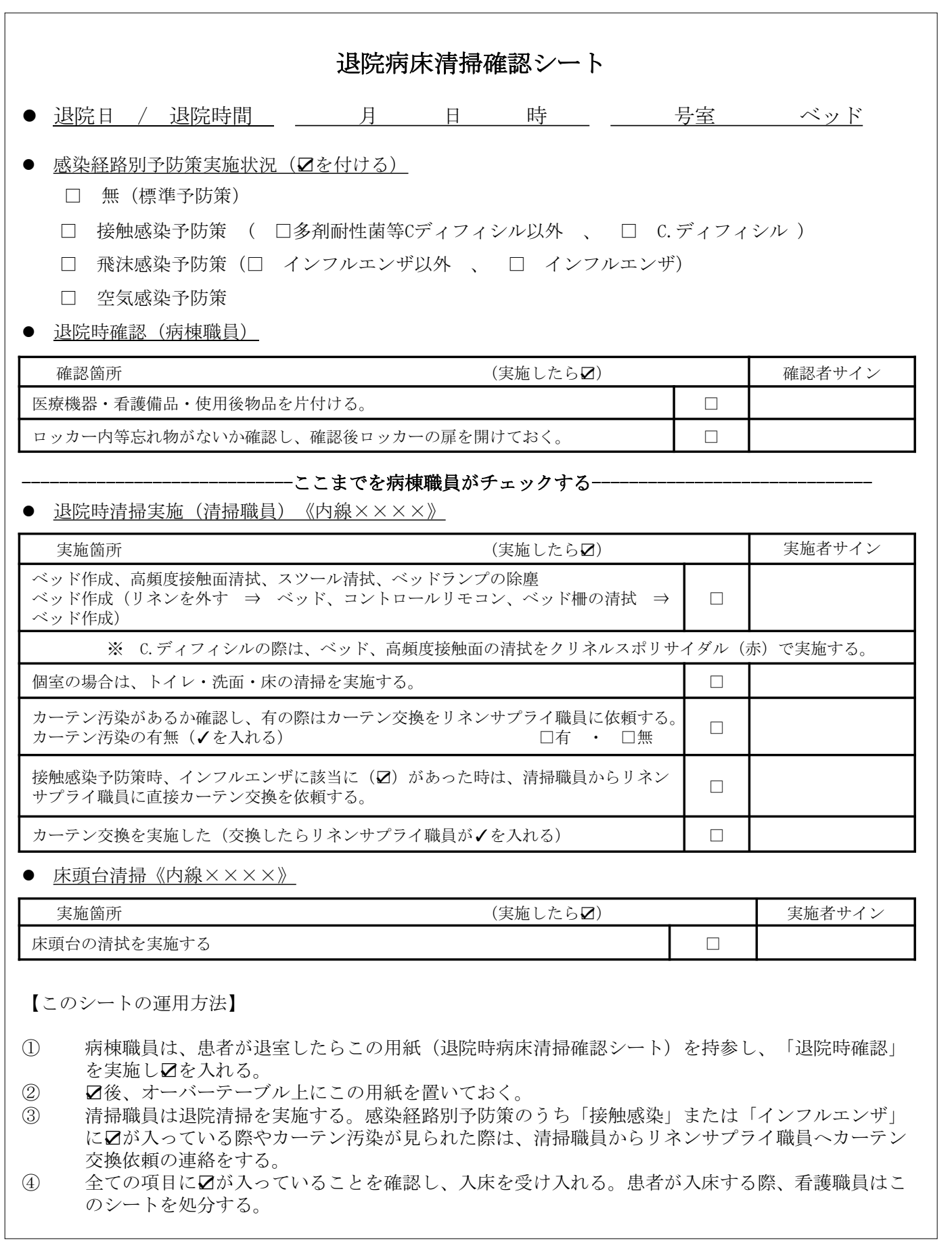

园 2 退院病床清掃確認シート

確認シートに沿って退院病床清掃を実施する.

備は, 病院の美化の目的のみではなく, 患者や職員を感 染のリスクから守る目的がありますが，その目的を意識 して業務が行えていますか?」の質問に対し，9割以上 の外部委託清掃職員が「目的意識を持っている」「どち らかというと目的意識を持っている」と回答した（図 3). 委託職員からは「この部分は感染リスクの高い場所に なると思います」「このようにしたらどうでしょうか」と
いった意見や提案が聞かれるようになった，体制を構築 しチーム活動を開始したことで, 病院職員と委託職員と が顔の見える関倸になり，意見や提案，相談がしやすい 状況に変化したと推測される。病院職員では気づけない 問題点についても明らかとなり, 改善につなげられた筒 所も増えている. 問題提起した事項について共有し, 検 討, 改善につなげられる事が, 委託職員にとっては一意 


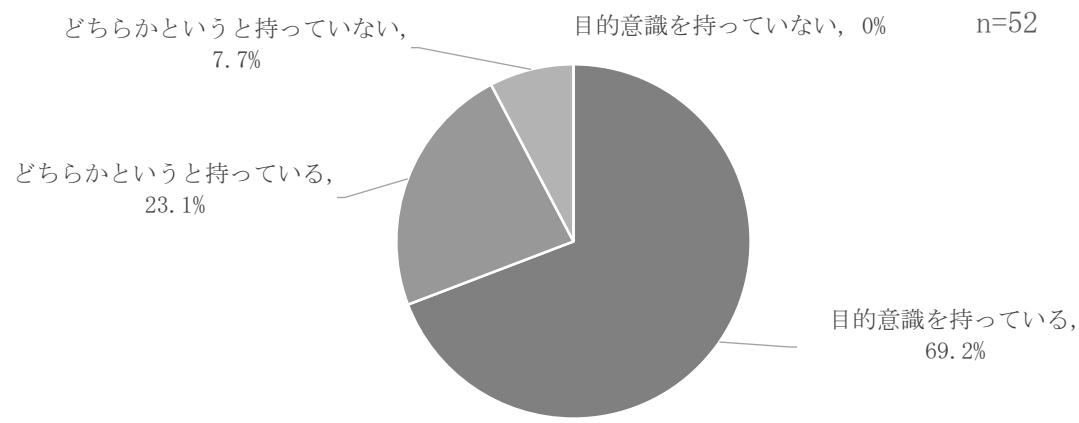

図 3 当施設委託清掃職員へのアンケート調査結果

「清掃や環境整備は, 病院の美化の目的のみではなく，患者さんや職員を感染のリスクから 守る目的がありますが, その目的を意識して業務が行えていますか?」の設問に対する回答

見として尊重された結果であると認識し,さらなる意識 の向上へとサイクルしているのではないだろうか.

また，アンケートでは「病院職員にかけてもらって嬉 しい言葉」についても質問した，回答として「きれいに してくれてありがとうございます」「助かります」「おつ かれさまです」といった感謝や労いの言葉があげられた. 感謝や労いの言葉は, 互いのやり取りをスムーズにし, 円滑なコミュニケーションへとつなげる効果がある。ま た認められたと実感することで,さらなる意識の向上, 意欲の増加につながるのではないだろうか.

委託職員の実際の作業状況を確認しているが, 現在で は，活動前に見られた問題と感じる場面に遭遇する機会 はなくなっている．また必要な瞬間での手指衛生の実施, 個人防護具の適正使用における遵守状況は良好である。

チーム活動を開始し，環境衛生を担う委託職員の目的 意識や役割認識は確実に向上し, 結果として環境衛生の 質は向上した。また，現在までに薬剤耐性菌，インフル エンザ, Clostridioides difficile 感染症によるアウトブレ イクは発生していない．環境衛生に関わる体制の構築と チーム活動が医療関連感染制御に貢献すると示唆された。

\section{おわりに}

病院や施設内には多くの委託職員が従事している。病 院職員と委託職員は同じ施設内にいながら, 互いの活動 を理解し，目的を共有しているとは言い難い.しかし， 委託職員も病院職員と同様, 立場は違うが重要な役割を 担うチームの一員である。目的意識を持った活動が行え るように，働きかけることが重要となる，殊に環境衛生 に係る委託職員に関しては，医療関連感染制御の土台を 支える重要な役割を担っている，感染管理担当者として 関わらなければ，環境衛生の質の向上は期待できない。
現在当施設では，清掃業務委託先の決定には，入札方 式ではなくプロポーザル方式（事業提案方式）を導入し ており, 協議や交渉が行いやすい利点が得られている. しかし, 今後導入方式が変更となり, リソースの削減か ら環境衛生の質の確保が困難となる可能性も視野に入れ ておく必要がある。，その際にも今回と同様の手法が通用 するのか課題が残る。いかなる状況においても, 環境衛 生が組織文化として醸成することを期待したい.

委託職員への感謝の気持ちを大切に，今後も活動を継 続していく.

本論文は第 35 回環境感染学会総会, 学術集会「Meet the Expert 5 『外部委託職員と協働して行う環境衛生』」の講演内容をまとめ たものである。

利益相反自己申告：申告すべきものなし．

\section{文献}

1) Kramer A, Schwebke I, Kampf G: How long do nosocomial pathogens persist on inanimate surfaces A systematic review. BMC Infect Dis 2006; 6: 130.

2) Mitchell BG, Dancer SJ, Anderson M, Dehn E: Risk of organism acquisition from prior room occupants a systematic review and meta-analisis. Journal of Hospital Infection 2015; 91(3): 211-7.

3) 平成 30 年度医療関連サービス実態調查結果の概要 一般財 団法人医療関連サービス振興会 : https://ikss.net/about/re search_list/h30-jittaichousakekkanogaiyou/.

4）医療法施行規則 9 条 15 （昭和 23 年厚生省令第 50 号）：htt ps://www.mhlw.go.jp/web/t_doc?dataId $=80092000 \&$ dataT ype $=0 \&$ page $\mathrm{No}_{0}=1$.

〔連絡先：`949-7302 新潟県南魚沼市浦佐 4132 新潟県地域医療推進機構魚沼基幹病院医療安全管理室 目崎 恵

E-mail:m-mezaki@ncmi.or.jp] 


\title{
Environmental Hygiene in Collaboration with Outsourced Staff
}

\begin{abstract}
Megumi MEZAKI
Medical Safety Management, Uonuma Kikan Hospital, Niigata Prefectural Community Medicine Institute

\section{Abstract}

Environmental hygiene is an important factor in controlling healthcare associated infections. Most healthcare facilities in Japan outsource environmental hygiene work such as cleaning, and not only hospital staff but also outsourced staff assume an important role in healthcare-related infection control. Improving the quality of environmental hygiene cannot be expected by outsourced staff alone unless infection control personnel are actively involved. We have built a team to respond to environmental hygiene and have developed a system for hospital staff and outsourced staff to work together. As a result, the sense of purpose of the outsourced staff and the quality of environmental hygiene have improved. Our team has ever controlled outbreaks from drugresistant bacteria, influenza, and CD infections. It is suggested that the activities and systems of our team have been successful.
\end{abstract}

Key words: environmental hygiene, outsourcing, team 